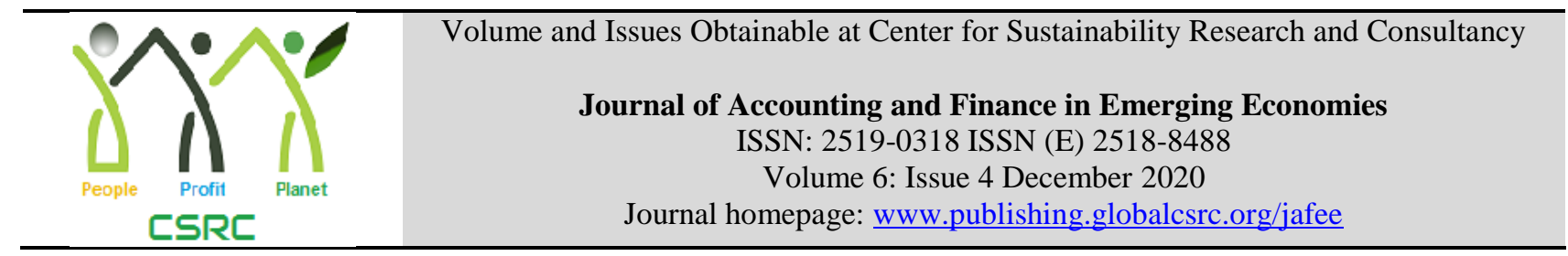

\title{
Relationship between Accounting Conservatism and Investment Efficiency with the Moderating Role of IFRS Adoption in Pakistan
}

\author{
${ }^{1}$ Khalid Latif, ${ }^{\mathbf{C}}$ Ghulam Mujtaba Chaudhary, ${ }^{3}$ Aon Waqas \\ ${ }^{1}$ Assistant Professor, College of Commerce, Government College University Faisalabad, Pakistan, \\ Khalidlatif@gcuf.edu.pk \\ ${ }^{2}$ Assistant Professor, University of Kotli Azad Jammu and Kashmir, Pakistan, \\ ghulam.mujtaba@uokajk.edu.pk \\ ${ }^{3}$ M.Phil Scholar, Government College University Faisalabad, Pakistan, waqasaon@ gmail.com
} ARTICLE DETAILS ABSTRACT

History:

Revised format: November

2020

Available Online: December 2020

\section{Keywords:}

Accounting Conservatism;

Investment Efficiency; Agency

Problem; IFRS Adoption

JEL Classification:

MO, M1
This study investigated the mandatory role of IFRS adoption in the association of accounting conservatism and investment efficiency in Pakistan. The study applied the model of Basu's (1997) to measure the conditional accounting conservatism for timely recognition of expected loss and gain. For empirical analysis, the study took a sample of 165 firms listed at Pakistan Stock Exchange and employed panel data methodology over the data of 2008-2017. Firms size, leverage, return on assets, and growth are taken as control variables to assess the relationship between accounting conservatism and investment efficiency. Findings of the study revealed that conditional accounting conservatism significantly affected the firms' investment efficiency with the mandatory adoption of IFRS in Pakistan. IFRS adoption enhanced the firms' investment efficiency and motivated to adopt the principle of accounting conservatism for recognizing the expected losses in timely manner in order to achieve investment efficiency. Timely recognition of expected losses played an important role in reducing agency problems and asymmetric information. In Pakistani setting, it is the pioneer study which highlighted the importance of accounting conservatism in protecting the surplus resources of investors and enhancing the overall investment efficiency under mandatory adoption of IFRS. These findings offer policy implications for focusing on the adaptation of IFRS in Pakistan.

(C) 2020 The authors, under a Creative Commons AttributionNonCommercial 4.0

Corresponding author's email address: Khalidlatif@ gcuf.edu.pk

Recommended citation: Latif, K., Chaudhary, G. M. \& Waqas, A. (2020). Relationship between

Accounting Conservatism and Investment Efficiency with the Moderating Role of IFRS Adoption in

Pakistan. Journal of Accounting and Finance in Emerging Economies, 6(4), 1139-1150

\section{Introduction}

The ongoing developments in today's world, especially in developing countries, are being considered initiatives to progress but various economic issues create hurdles to achieve the targets. The developing economies need an appropriate way to use the surplus of wealth in better investment opportunities to 
overcome these economic issues (Wang, Zhu et al. 2015). In this regard, one of the best approach is expansion and development of efficient investment because the efficient investment is carried out by firms in different projects, have been considered as a tool to bear the shocks of recession periods (Hayati and Sedaghat 2016). The changing environment of world arise the need of proper and practical solutions to use surplus cash flows in the efficient investments. When a firm invests in the projects, it leads to the physical development of the country and it creates employment opportunities and when a firm invests in the shape of capital it leads to the development of capital markets. That is why the investment decisions are important to the firm as well as for the economy. Further, the quality of investment should be focused, rather than the quantity of investment.

In the absence of frictions like adverse selection or agency cost, firms focus on those projects which have a positive net worth at the current period. Generally speaking, investment efficiency refers to accept those projects which have positive NPV and neglect to those which have negative NPV in the current period (Lara, Osma et al. 2016). Investment efficiency is deeply subject to agency problems which easily leads to select the projects having negative net present value (Over-Investment) and neglecting of positive NPV's projects (Under-Investment) by managers for their benefits. Both ways of investment (Over and Under Investment) belong to inefficiency in investment which will cause to loss of surplus resources so firms try to measure the loss by approaching the accounting conservatism principle to bring efficiency in investment by the anticipation of loss before accruing (Stein 2003).

Financial statements disseminate the internal information to stakeholders, however, the authenticity of this information cannot be certified, so there is lack of transparency (Dayanandan, Donker et al. 2016). The reported earnings are the main concern for the managers, investors and stakeholders (Shan 2015) and External capital providers rely on earnings regardless of other determinants. Earnings are of good quality if are a good indicator of future earnings (stable earnings), consequently, when an accounting treatment produces volatile earnings, those volatile earnings are estimated to be of poor quality. Accounting conservatism is a fundamental feature of quality of financial reporting, as it is improves the reliability of financial statements and reduces information asymmetry (Mohammed, Ahmed et al. 2017). Conservatism reduces agency conflict in three ways. First, it limits management overpayment to them and other parties with its timely recognition of losses and delayed recognition of profit (Watts, 2003). Second, it prevents managers from investing in negative net present value (NPV) projects (Delkhosh and Sadeghi 2017). Third, managers are more likely to abandon negative NPV projects under conservative accounting because it causes economic losses from these projects recognized on a time basis (Watts, 2003).

In this connection, International Financial Reporting Standards (hereafter IFRS) which are being adopted in different economies that provide assistance for efficient investment as moderator and improve the transparency as well as the comparability of accounting information (Barth, Landsman et al. 2008); (Lee 2011). IFRS were introduced by IASB by improving IAS in 2004 which leads to higher accounting quality, more market liquidity, and the lowest cost of capital. The goal of IFRS is the only provision of useful information for decision making about investment, IFRS provides that information in time as compare to domestic GAAP therefore, we expect more chances of overall efficient investment for that firm which is adopting international financial reporting standards because that firm's investors are more able to monitor the management of the firm concerning efficient investment decisions (Lu and Trabelsi 2013). Financial economic theories state that the optimal investment process of a firm is mostly driven by the information asymmetry among firms and capital providers about how much surplus of resources are allocated by firms for investment opportunities and information asymmetry is another determinant of accounting conservatism (LaFond and Watts 2008). Additionally, accounting conservatism is helpful to avoid opportunistic behaviors of a firm's management which leads to an increase in the value of the firm by choosing efficient investment-based projects. In accounting-based policies, accounting conservatism is a basic fundamental principle which is being used from last three eras, and for financial information, accounting conservatism principle is considered as most useable 
attribute however the acceptability for economic and investment benefits of this is like a question among policy setters and academicians (Whittington, 2014). IFRS are accounting rules and standards issued by an independent organization known as IASB by updating IAS since 2001 to enable the users of financial statements to compare their statements with other countries. Pakistan has made many changes in its accounting standards according to international standards like IFRS. In this regard, SECP has directed the companies as per the direction of IACP to compliance the IAS / IFRS under section 234 of companies' ordinance 1984. IFRS adoption is considered an appropriate set of IAS. Pakistan is one of the few economies that have started to apply the updated IAS since 2003. As ICAP is responsible for all accounting rules and regulations, has directed that all public companies listed in PSX are required to prepare their Financial Statements according to the updated IAS while IFRS is being adopted without making any alternation in such updated standards excluding IFRS 1 and IFRS 6 under the proper guidance of ICAP since 2007. Pakistan has not adopted IFRS 1 and 14 and IFRS 9 has been deferred until $30^{\text {th }}$ June 2021. During the exemption period, companies are following the requirements of IAS 39.

\section{Literature Review}

Studies on accounting conservatism and investment efficiency are substantial and largely grounded upon agency theory and positive accounting theory. Quality of earnings figure is assumed an important element for the financial reporting of firms and firm's performance in developed economies. However, in developing economies like Pakistan, it is expected that the financial reporting characteristics are not so effective the reduction of agency conflict due to the influential power of shareholders control and delicate legal enforcements. Conservatism limits the intent of managers to improve the explanation power of financial figures of firms. Thus, conservatism is a necessary approach to managing insecurity or inherent risks in transactions as it may protect the interests of stakeholders (Watts 2003). Conservatism can serve as a constraint on opportunistic managerial behavior, compensating for managerial biases by affecting asymmetric information and in a sense, conservatism improves the quality of earnings (Ahmed and Duellman 2007, Chen, Hemmer et al. 2007, Lara, Osma et al. 2009, García Lara, Garcia Osma et al. 2012).

In literature, conservatism is defined in many ways. For instance, as per first definition of Bliss (1924) conservatism means "anticipate losses rather to anticipate gains". Basu (1997) viewed that earnings replicate the bad news quickly as compared to good news. Givoly and Hayn (2000) define conservatism as the choice of accounting principles that minimize reported cumulative earnings by slowing the recognition of income, faster recognition of expenses, lower the valuation of assets and higher valuation of liabilities. Under the current GAAP, conservatism applies to the measurement of wealth and recognition of income and expenses; tends to guide accountants to choose accounting methods in in favor of slower revenue recognition and lower valuation of net assets. This study follows the Basu's (1997) model for the measurement of conservatism. Efficient allocation of capital theory endorses that the firm should avoid to invest funds in those projects having negative rate of return (Bushman, Piotroski et al. 2011). Sound quality of financial statements helps the stakeholders to allocate their resources efficiently by diminishing the asymmetric information and financial reporting quality enhances the investment efficiency (Guo, Huang et al. 2020). Conservatism deters the opportunistic behavior of managers, not allow them to invest in the projects having negative Net Present Value or negative rate of returns and also prevent them to defer the losses to offset in the future. Conservatism accounting enhances the reporting quality, reduces the information asymmetry and resolves the problem of investment inefficiency (Chen et al., 2011; Guay and Verrecchia (2018).

Prior studies show that conservatism impacts positively the Investment Efficiency up to much extent. This type of impact produces in different forms. The first one can be observed in the form that conservatism which mitigates the level of asymmetric information between shareholders and managers and results in the reduction of the cost of adverse selection (Bushman, Piotroski et al. 2011), decreasing the cost of borrowing the external capital (Houcine 2017), and increasing the monitoring and controlling. It implies that managers are not much biased, the conflict of interest is lowest and they are 
less likely to make those decisions which are biased or that are related to agency conflicts such as risk shifting, empire building and risk avoidance. The second form of this impact can be observed that if the quality of reporting and financial information is higher, it reflects "truthful" and unbiased representation which allows the employees and managers to make the predictions, planning and economic decisions on the basis of real situation of the firm.

(Bushman, Piotroski et al. 2011) state that low investment opportunities enhance the chances of accounting conservatism but finds that also there is no increase in the efficient investment process and opportunity by recognition of losses in time (Bushman, Piotroski et al. 2005). Mak, Strong et al. (2011) expand the accounting conservatism model and adoption to achieve investment efficiency by timely estimation of expected unfavorable cash flows among the United Kingdom listed firms while they find strong evidence about the use of conservatism principle of accounting for efficient investment. Roychowdhury (2010) and Guay and Verrecchia (2018) found that the conservatism constraints the role of manager as well as overcomes the agency problems which leads towards investment efficiency by gaining from over-investment patterns and on the other side accounting conservatism may become the cause of abnormal investment concerning incentives for mangers that directly neglect the positive NPVs projects means to say an under-invest pattern of a firm.

Theoretical argument suggests that IFRS influences the asymmetric information among stakeholders by increasing the accounting information transparency and comparability (Abad, Cutillas- Gomariz et al. 2018). As stated earlier, minimum information gap leads to investment efficiency which reflects that optimal corporate investment is the result of IFRS adoption. Schleicher, Tahoun et al. (2010) examined the link between IFRS and investment efficiency in European countries and find that application of IFRS makes stronger sensitivity of cash flows and suggest that more cash flows result more investment opportunities. Márquez-Ramos (2008) investigates that the accounting process is a way to decrease the informational cost to enhance international investment, furthermore, concludes that adoption of IFRS has impacts on the European economy and "companies of different economies are expected to take part in opportunities of foreign investment with great extent" and this study also contributed that IFRS adoption in "risk-averse countries" has many fruitful results in term of FDI. Florou and Pope (2012) show that "the adoption of IFRS enhances the investors demand as well as an increase in institutional holdings by IFRS adaptors" while the mandatory adoption of IFRS leads to higher FRQ which motivates the firms to invest in efficient projects relatively compare to GAAP. André, Filip et al. (2014) examines the investment efficiency relationship along with accounting conservatism and IFRS adoption by French firms and finds that IFRS adoption balance the difference of over-under investment by considering that conservatism as an accounting quality factor for financial reporting. Chen, Young et al. (2012) elaborate the effect of IFRS adoption on investment efficiency of almost 17 EU countries' firms and also gauge the effect of firms return on the asset on investment efficiency for the same population. In conclusion remarks they support that argument that after the adoption of IFRS affects the firm's return on an asset as well as a decrease in over-investment and increase in under-investment that means an efficient investment of firm respectively. Balfoussia and Gibson (2018) study the relationship between corporate investment and financial condition in European countries after mandatory adoption of IFRS and find that "financial conditions are in control and play an important role for investment decisions after IFRS adoption". Louis and Urcan (2014) Study to examine that what is leading role of mandatory adoption of IFRS in "cross-border acquisitions into adoption and non-adoption countries" so they find that there is a significant enhancement of the flow of investment in those countries' listed firms which adopt the IFRS. Shima and Gordon (2011) research in the United State to investigate the relationship of international investment made by US investors in other economies after the implementation of IFRS and say that there is a significant positive association between US investment and adoption of IFRS with proper enforcement of regulation and legal system. IFRS adoption reduces informational conflicts among managers and investors, outsiders and insiders, means have a positive impact on the investment efficiency of firms and the other hand, IFRS are recognized as improvements in accounting conservatism (André, Filip et al. 2014). 


\section{Methodology}

The sample of the study consists of listed firms in the Pakistan Stock Exchange for the years 2008 to 2017. Financial firms and insurance companies are excluded from the sample because of differences in reporting structures and regulations (Firth, Fung et al. 2007). Firms with insufficient data are also excluded and final sample consist of 165 firms after the adjustment of outliers. We extract the financial data directly from the annual reports of non-financial firms.

\subsection{Measurement of Accounting Conservatism}

Managers can do earning management by using two ways. Either through intentionally manipulation in accruals or through influence in real activities. In first method, only accruals are manipulated and operating activities and cash flows are not affected. It means that only performed activities are manipulated. However in the second method, managers involve in manipulation of firm's events that have an impact on earnings. Such type of manipulation has direct impact on cash flows. The managers and firms give discount to enhance sales for the time being, operates overproduction and cut in discretionary expenses, to increase the earning figure. To detect the timely loss recognition, first proxy developed by (Basu 1997). This model is based on the assumption that when losses are incurred, market efficiency reflects in returns. In this empirical study we use the Basu model to measure the conditional conservatism by using earnings-returns association as under:-

$$
\frac{\operatorname{NInCOME}_{j, t}}{M V E_{t-1}}=\beta_{1}+\beta_{2} D_{t}+\beta_{3} \operatorname{SRET}_{t}+\beta_{4} D_{t} X \operatorname{SRET}_{t}+\varepsilon_{t}
$$

Where: NinCOME represent net income in time; MVE shows the market value of equity at the beginning of time t; $D_{t}$ is a dummy variable, 1 if $S R E T_{t}<0$ and 0 otherwise and SRET is the stock price return at time t. $\beta_{3}$ is the measure of good news timeliness and $\beta_{4}$ is a measure of incremental effect of bad news timeliness over good news timeliness. Higher $\beta_{4}$ reflects the higher level of timely loss recognition i.e If bad news is recognized in a more timely fashion than good news, $\beta_{4}$ will be greater than zero $\left(\beta_{4}>0\right)$. Higher timely loss recognition depicts the good level of earning quality.

\subsection{Measurement of Investment Efficiency}

Investment efficiency is a dependent variable of this study we represent the firm is working efficiently if firms undertake investments with positive NPV so as per previous studies, investment efficiency is measured as deviations from expected investment using a model that predicts investment as a function of growth opportunities so both types of investments as over investment and under-investment are considered as inefficient investments made by firm (Biddle, Hilary et al. 2009). This model is based on the firm's sales value shows that the firm is expecting efficient investment;

$$
\text { Investment }=\alpha_{0}+\beta_{1} \text { Sales }_{i t}+\varepsilon_{i t}
$$

Positive residuals represent that there are positive deviations from expected investment means overinvestment which suggests that selection of negative NPV's projects by firm but if calculated residues would be negative, it means that negative deviation from an expected investment of firm which represent the under-investment. In this model if $\boldsymbol{\varepsilon}_{\boldsymbol{i t}}<\mathbf{0}=$ under-investment while if $\boldsymbol{\varepsilon}_{\boldsymbol{i t}}>\mathbf{0}=$ overinvestment.

\subsection{Measurement of IFRS}

International reporting standards adopted as moderating variable in this study which is being estimated by considering as a Dummy Variable (Piot, Dumontier et al. 2011) (Piot, Janin et al. 2010). Coded one if a firm reported the financial statements under IFRS otherwise coded zero.

\subsection{Empirical Models}

To test the hypothesis, a multiple regression analysis is used. To check the multicollinearity, correlation analysis is and ensured that the data is free from this issue. Other diagnostic tests are also applied and 
following (Omware, Atheru et al. 2020), we use the following three regression equations to investigate the relationship between investment efficiency and accounting conservatism with the moderating role of IFRS:-

$$
I N E F_{i t}=\alpha+\beta A C O N_{i t}+\Upsilon I F R S_{i t}+\xi S I Z E_{i t}+\varphi L E V_{i t}+\tau G W_{i t}+\lambda R O A_{i t}+\varepsilon_{i t}
$$

Where $I N E F_{i t}=$ Investment Efficiency, $A C O N_{i t}=$ Accounting Conservatism. $I F R S_{i t}=$ International Financial Reporting Standards, $S I Z E_{i t}=$ logarithm of total assets, $L E V_{i t}=$ Debt to Equity, $G W_{i t}=$ Market Value of Equity / Book Value of Equity, and $R O A_{i t}=$ Net Income / Total Assets; and $\varepsilon_{i t}=$ Error term. $i$ is the number of firms $1,2,3 \ldots \ldots . . N$ and $t$ is the number of years $1,2,3 \ldots \ldots$.

To address the moderating role of IFRS adoption, equation 4 with the introduction of the interactive term is expressed as under:-

$I N E F_{i t}=\alpha+\beta A C O N_{i t}+\gamma I F R S_{i t}+\eta A C O N_{i t} * I F R S_{i t}+\xi S I Z E_{i t}+\varphi L E V_{i t}+\tau G W_{i t}+\lambda R O A_{i t}+$ $\varepsilon_{i t}$

The sign of coefficient of the interactive term $(\eta)$ express the moderating role of IFRS that whether IFRS adoption distort or enhance the association among accounting conservatism and investment efficient in the context of Pakistan. A positive sign indicates that the IFRS adoption increases the association and negative sign indicates the distortion of the relationship of the conservatism and investment efficiency.

To gauge the total effect of IFRS adoption on the association of conservatism and investment efficiency, the equation is expressed as:-

$$
\frac{r I N E F}{r C A O N}=\beta+\eta \operatorname{IFRS}
$$

Given that $\beta$ is expected to be positive, if the positive sign of $\eta$ is greater than the positive sign of, this implies that IFRS adoption is sufficient to enhance the "positive" effect of Conservatism on investment efficiency.

\subsection{Control Variables}

Following control variables are taken into account in this study.

\subsubsection{Firm size (FS)}

Prior studies use the company size as a determinant variable of firm investment magnitude, economic and financial performance and as a determinant of financial reporting quality. Big firms are motivated to explain optimistic results on investment horizons (Prior, Surroca et al. 2008). Moreover the size of the company has been used in many research studies concerning financial reporting quality, but these consequences are uncertain (Martínez-Ferrero 2014). Corporation size is estimated by taking the natural logarithm of firm's total assets.

\subsubsection{Leverage (LVG)}

High levered firms are induced to underinvestment (Bistrova, Lace et al. 2011) and leverage is the risk of debt or default and it can be measured by taking the ratio of debt to equity. Different variables commonly used in earlier studies are the rank of leverage (DEBT). But it was found that debt ratios are the main determinants of earnings management changes (Martinez, 2014).

\subsubsection{Growth (GW)}

Previous research suggests that managers have an incentive to engage in excessive investment to expand their companies' business beyond the ideal level and to consume benefits when their companies experience a high level of growth (Richardson 2006). Growing a firm is expected to enhance the firm's 
value therefore we include the level of growth as a control variable in this study. GW is measured by dividing the market value of equity by the book value of equity (ratio of equity) belong to the firm (Billett, King et al. 2007).

\subsubsection{Return on Asset (ROA)}

Many existing studies demonstrate that larger and more profitable enterprises prefer financial stability and conservative management, preventing managers from getting involved in excessive investment, so we gauge the company profitability, which can be calculated as shared net profit of the total assets held by the company (Frederickson and Hilary 2006).

\section{Empirical Results}

Descriptive statistics is applied for the purpose to summarize the attributes of data. Table-1 elaborate the key descriptive statistics values of the adopted factors of the study.

Table-1 Descriptive Statistics

\begin{tabular}{|l|l|l|l|l|}
\hline Variable & Mean & S. D. & Minimum & Maximum \\
\hline INEF & 0.5224 & 0.2240 & 0.0073 & 0.9995 \\
\hline ACON & -0.3045 & 1.3249 & -1.2055 & 4.5398 \\
\hline IFRS & 0.6000 & 0.4900 & 0 & 1 \\
\hline ACONxIFRS & -0.1874 & 1.8995 & 0 & 4.5398 \\
\hline ROA & 0.0719 & 0.1327 & -1.2070 & 0.8062 \\
\hline SIZE & 5.0990 & 1.6914 & 3.7102 & 9.0230 \\
\hline LEV & 0.4802 & 0.2578 & 0.2456 & 0.7369 \\
\hline GW & 0.4333 & 1.7248 & -0.0389 & 0.6137 \\
\hline ROA & 0.2435 & 1.8972 & -0.0452 & 0.9835 \\
\hline
\end{tabular}

As concern with table-1, investment efficiency has a mean value of 0.5224 , the value of overall standard deviation is 0.2240 with the minimum value of investment efficiency (overall) is 0.0073 and the overall maximum value of investment efficiency is 0.9995. These statistics indicate that firms are involved in over investment strategies as mean value is positive. The descriptive results of accounting conservatism are: mean value is -0.3045 while standard deviation is 1.3249 and overall minimum and maximum values are -1.2055 and 4.5398 respectively. Positive value of ACON shows that the firms use the principle of conservatism. IFRS has a mean value of 0.6000 , the value of standard deviation is 0.4900 with minimum value of international financial reporting standards (overall) is 0 maximum value of IFRS is 1. The descriptive results about the interactive term of IFRS and conservatism (ACONxIFRS) are such as: mean value is -0.1874 while standard deviation is 1.8995 and the overall minimum and maximum values are 0 and 4.5398 respectively. The descriptive results of return on asset (ROA) show that the mean value is 0.0719 while standard deviation is 0.1327 overall and the overall minimum and maximum values are -1.2070 and 0.8062 respectively. The descriptive results of firm size (SIZE) are; mean value is 5.0990 while standard deviation is 1.6914 and the overall minimum and maximum values are 8.7102 and 20.0230 respectively. Mean value of firm leverage (LEV) is 0.4802 , standard deviation is 0.2578 , overall minimum value is 0.2456 and maximum value is 0.7369 respectively. These leverage results show that firms in Pakistan rely on debt. The descriptive results of firms' growth $(\mathrm{GW})$ show that the mean value is 0.4333 while standard deviation is 1.7248 overall with minimum and maximum values -0.0389 and 0.61378 respectively.

The correlation matrix provides an assistant to check the issue of multicollinearity among sample variables. There is a phenomenon in which two or more independent variables are too correlated with each other in multiple regressions. The correlation matrix also tells and presents the relational strength of independent variables of the study.

Table-2 identifies the strength of the relationship among variables which indicates that the correlation between accounting conservatism and investment efficiency is 0.1823 . Correlation between IFRS and 
INEF is also positive 0.1134 and the relationship among interactive term and INEF is 0.1134 . The relationship between INVEFFI and ROA is 0.1905 which indicates the positive association between investment efficiency and return on asset. While table value of size 0.3860 shows the positive relationship between INEF and SIZE, furthermore, above table also explains the negative correlation of investment efficiency and firms' leverage by showing value as -0.3713 . Firms' growth is positively associated with investment efficiency suggesting that firm with growth opportunities have involved in efficient investments. This correlation matrix;

Table -2 Correlation Matrix

\begin{tabular}{|c|c|c|c|c|c|c|c|c|c|}
\hline Variable & INEF & $\mathrm{ACON}$ & IFRS & ACONxIFRS & ROA & SIZE & LEV & GW & ROA \\
\hline INEF & 1.0000 & & & & & & & & \\
\hline $\mathrm{ACON}$ & 0.1823 & 1.0000 & & & & & & & \\
\hline IFRS & 0.1134 & 0.2536 & 1.0000 & & & & & & \\
\hline ACONxIFRS & 0.0027 & 0.3817 & 0.0140 & 1.0000 & & & & & \\
\hline ROA & 0.1905 & 0.0200 & 0.036 & 0.0187 & 1.0000 & & & & \\
\hline SIZE & 0.3860 & 0.0221 & 0.0783 & 0.0362 & 0.1722 & 1.0000 & & & \\
\hline LEV & -0.3713 & 0.0168 & -0.0060 & 0.0141 & -0.3528 & -0.1355 & 1.0000 & & \\
\hline GW & 0.1953 & -0.0064 & 0.0287 & 0.0023 & 0.4079 & 0.0507 & -0.1721 & 1.0000 & \\
\hline ROA & 0.3246 & 0.4814 & 0.2460 & 0.2917 & 0.2754 & 0.3702 & 0.3065 & 0.3520 & 1.0000 \\
\hline
\end{tabular}

represents that there is no any correlation coefficient is higher than 0.50 . We have calculated the variance inflation factor for each explanatory variable (results not shown here) and it is confirmed that there is no problem of multicollinearity exists in the data series.

\subsection{Regression Results}

For the panel data analysis, Hausman test is applied for the selection between random effect and fixed effect models. Panel data analysis covers the heterogeneity of firms and captures time variations effect as well. As concerned with the above-stated test the P-value is less than 5\% which means that fixed effect model is appropriate for the estimation of data. Main results are reported in Table 3 and it is clear that in all regression characteristics, the value of $\mathrm{R}^{2}$ is high along with the statistically significant value of F- statistics, both supports the reliability of the results. Keeping the other factors same, the results indicate that ACON has a positive significant association with INVEFFI as p-value is less than 0.05 and also the coefficient value of ACON is 0.05653 which means that 1 unit change in accounting conservatism will cause of $5.6 \%$ positive change in investment efficiency. These results approve that conservatism leads to investment efficiency and deters the managerial opportunities behavior and enhance the information asymmetry. These findings are aligned with the results of (Lara, Osma et al. 2016).

Table -3 Results of Fixed Effect Model

\begin{tabular}{|c|c|c|c|c|}
\hline \multirow[t]{2}{*}{ Variables } & \multicolumn{2}{|c|}{ Model-1 } & \multicolumn{2}{|c|}{ Model-2 } \\
\hline & Coefficient & Prob. & Coefficient & Prob. \\
\hline $\mathrm{ACON}$ & 0.0565 & 0.0324 & 0.0749 & 0.0492 \\
\hline IFRS & 0.0323 & 0.0154 & 0.0393 & 0.0162 \\
\hline ACON*IFRS & ----- & ----- & 0.0927 & 0.0456 \\
\hline SIZE & 0.0675 & 0.0360 & 0.0879 & 0.0030 \\
\hline LEV & -0.0328 & 0.0472 & -0.0290 & 0.0391 \\
\hline GW & 0.0086 & 0.0078 & 0.0551 & 0.0012 \\
\hline ROA & 0.0762 & 0.0386 & 0.0159 & 0.0430 \\
\hline CONS. & 0.0927 & 0.0582 & 0.0769 & 0.0462 \\
\hline F-Stat & \multicolumn{2}{|c|}{$\begin{array}{c}3.1400 \\
(0.0152)\end{array}$} & \multicolumn{2}{|c|}{$\begin{array}{c}2.5076 \\
(0.0408)\end{array}$} \\
\hline Adj. R-Square & \multicolumn{2}{|c|}{0.4946} & \multicolumn{2}{|c|}{0.5087} \\
\hline
\end{tabular}

The coefficient of IFRS (0.0323) shows that a 1 unit change in IFRS is caused a change of $3.23 \%$ in investment efficiency at $5 \%$ level of significance. These findings suggest that set of IFRS reduces the 
asymmetric information by increasing the comparative power of financial statements and stakeholders can recognize the good or bad investment horizons. Taken together, these results provide evidence that the mandatory adoption of IFRS seems to alleviate the information asymmetry between the minority and majority shareholders in countries where several investors exercise significant control over resources and assets. Firm's Size, growth, leverage and profitability are served as control variables to determine the investment and financial decisions (Biddle, Ma et al. 2020). The positive and significant magnitude of size indicates that large firms have better investment performance as compared to small concerns.

In model-2, IFRS has significant positive effect (0.0393) on investment efficiency at 5\% level of significance indicating that a unit increase in the IFRS adoption cause around $3.93 \%$ increase in the selection of efficient investments. The coefficient of interactive term is 0.0927 (positive) and it occurs at and higher than 5\% level of significance. These results show that interactive term did not inhibit the relationship between accounting conservatism and investment efficiency of the firms. A positive sign indicates that the IFRS adoption increases the association of the conservatism and investment efficiency. To gauge the total effect as suggested in model-3, the coefficient of interactive term is positive which represent that IFRS adoption enhances the relationship of conservatism on investment efficiency. This coefficient is positive and significant at 5\% level. Influence of IFRS as a moderator is gauged through the magnitude of the interactive term as suggested in model-3. The value 0.1676 (i.e. $0.0749+0.01676$ ) represents the total effect of accounting conservatism on investment efficiency. These findings show that positive interaction is sufficient to enhance the positive association of conservatism and investment decisions. This is a significant contribution in the literature relating conservatism.

\section{Conclusion}

The purpose of this study is to identify the association of accounting conservatism and investment efficiency under the moderating role of IFRS adoption by Pakistani firms. This study also captures the impact of conservatism under the shadow of asymmetric information to the concept of agency theory (Aharony, Barniv et al. 2010). This study empirically proves that adoption of IFRS improves conservatism and conservatism enhances the efficiency in the investment of sample firms as (André, Filip et al. 2015) state such results in their research. Further, asymmetric information plays an important role towards the adoption of IFRS concerning enhance underinvestment and to reduce overinvestment while this study also contributes that, with the adoption of IFRS, more conservative sample firms invest more as the study of (Ahmed and Duellman 2011) present such impacts. In this study, the association between conservatism and IFRS adoption is significant which means that mandatory adoption of IFRS by Pakistani sample firms increases the opportunities to recognize expected loss in time to select those projects having positive NPVs and to neglect such projects which have negative NPVs to enhance the chances of efficient investment, however, as recent and last studies present that mandatory adoption of IFRS improves accounting conservatism along with improvement of investment efficiency also by such adoption by developed and underdeveloped economies (Aharony, Barniv et al. 2010); (Kythreotis 2014) and (Whittington 2014). Investors should motivate the firms to conduct conservative financial reporting under the proper implementation of IFRS to recognize the loss in time to achieve efficiency in investment made by them. The principle of accounting, conservatism is useful for investors of business firms to protect their investment and to enhance the value of the firm.

Regulatory bodies and standard setters should adopt the accounting principle of conservatism in the presentation of financial statements of firms under international reporting rules and regulations like IFRS rather than under local/national reporting standards such as GAAP, further, to motivate the firms' managers to show a fair picture of firms' position before the investors for efficient investment. Finally, the results of the adoption of such recommendations will be a reduction in agency and asymmetric information related conflicts respectively. This study considers few variables i.e. accounting conservatism; investment efficiency and post-adoption of IFRS in Pakistan only along with some control variables such as growth, size, and leverage while for future research, conservatism and investment efficiency can be tested through the relationship of conservatism with corporate governance, audit 
quality, FRQ, earning management and performance of other developing economies' firms belong to pre and post-adoption of IFRS by Sri Lankan and Indian firms, etc.

\section{References}

Abad, D., et al. (2018). "Does IFRS mandatory adoption affect information asymmetry in the stock market?" Australian Accounting Review 28(1): 61-78.

Aharony, J., et al. (2010). "The impact of mandatory IFRS adoption on equity valuation of accounting numbers for security investors in the EU." European Accounting Review 19(3): 535-578.

Ahmed, A. S. and S. Duellman (2007). "Accounting conservatism and board of director characteristics: An empirical analysis." Journal of accounting and economics 43(2): 411-437.

Ahmed, A. S. and S. Duellman (2011). "Evidence on the role of accounting conservatism in monitoring managers' investment decisions." Accounting \& Finance 51(3): 609-633.

André, P., et al. (2014). "The impact of IFRS on the relationship between conservatism and investment efficiency." Comptabilité-Contrôle-Audit 20(3): 101-124.

André, P., et al. (2015). "The Impact of IFRS on the Relationship between Conservatism and Investment Efficiency."

Balfoussia, H. and H. D. Gibson (2018). "Firm investment and financial conditions in the euro area: evidence from firm-level data." Applied Economics Letters: 1-7.

Barth, M. E., et al. (2008). "International accounting standards and accounting quality." Journal of accounting research 46(3): 467-498.

Basu, S. (1997). "The conservatism principle and the asymmetric timeliness of earnings 1." Journal of accounting and economics 24(1): 3-37.

Biddle, G. C., et al. (2009). "How does financial reporting quality relate to investment efficiency?" Journal of Accounting and Economics 48(2-3): 112-131.

Biddle, G. C., et al. (2020). "Accounting conservatism and bankruptcy risk." Journal of Accounting, Auditing and Finance, Forthcoming.

Billett, M. T., et al. (2007). "Growth opportunities and the choice of leverage, debt maturity, and covenants." the Journal of Finance 62(2): 697-730.

Bistrova, J., et al. (2011). "The influence of capital structure on Baltic corporate performance." Journal of Business Economics and Management 12(4): 655-669.

Bushman, R. M., et al. (2005). Capital Allocation and Timely Accounting Recognition of Economic Losses, University of Chicago.

Bushman, R. M., et al. (2011). "Capital allocation and timely accounting recognition of economic losses." Journal of Business Finance \& Accounting 38(1- 2): 1-33.

Chen, C., et al. (2012). "Externalities of mandatory IFRS adoption: Evidence from cross-border spillover effects of financial information on investment efficiency." The Accounting Review 88(3): 881914.

Chen, Q., et al. (2007). "On the relation between conservatism in accounting standards and incentives for earnings management." Journal of Accounting research 45(3): 541-565.

Dayanandan, A., et al. (2016). "IFRS and accounting quality: legal origin, regional, and disclosure impacts." International Journal of Accounting and Information Management 24(3): 296-316.

Delkhosh, M. and M. Sadeghi (2017). "The effect of accounting conservatism and earnings management on earnings quality." International Journal of Accounting and Economics Studies 5(2): 157-162.

Firth, M., et al. (2007). "Ownership, two-tier board structure, and the informativeness of earningsEvidence from China." Journal of Accounting and Public Policy 26(4): 463-496.

Florou, A. and P. F. Pope (2012). "Mandatory IFRS adoption and institutional investment decisions." The Accounting Review 87(6): 1993-2025.

Frederickson, J. and G. Hilary (2006). Disclosure quality and capital investment, Working paper, Hong Kong University of Science and Technology.

García Lara, J. M., et al. (2012). "Accounting conservatism and the limits to earnings management." Available at SSRN 2165694.

Guay, W. and R. E. Verrecchia (2018). "Conservative disclosure." Journal of Financial Reporting. 
Guo, J., et al. (2020). "Accounting conservatism and corporate social responsibility." Advances in accounting 51: 100501.

Hayati, K. and P. Sedaghat (2016). "An evaluation of the links between quality of reporting and efficiency of investment in companies listed at Tehran Stock Exchange." Problems and Perspectives in Management 14(2): 341-347.

Houcine, A. (2017). "The effect of financial reporting quality on corporate investment efficiency: Evidence from the Tunisian stock market." Research in International Business and Finance 42: 321-337.

Kythreotis, A. (2014). "Measurement of Financial Reporting Quality Based on IFRS Conceptual Framework's Fundamental Qualitative Characteristics." European Journal of Accounting, Finance \& Business 2(3): 4-29.

LaFond, R. and R. L. Watts (2008). "The information role of conservatism." The Accounting Review 83(2): 447-478.

Lara, J. M. G., et al. (2009). "Accounting conservatism and corporate governance." Review of Accounting Studies 14(1): 161-201.

Lara, J. M. G., et al. (2016). "Accounting conservatism and firm investment efficiency." Journal of Accounting and Economics 61(1): 221-238.

Lee, J. (2011). The Role of Accounting Conservatism in Firms' Financial Decisions, Northwestern University.

Louis, H. and O. Urcan (2014). "The effect of IFRS on cross-border acquisitions."

Lu, X. C. and S. Trabelsi (2013). "Information Asymmetry and Accounting Conservatism under IFRS Adoption."

Mak, C. Y., et al. (2011). "Conditional earnings conservatism and corporate refocusing activities." Journal of Accounting Research 49(4): 1041-1082.

Márquez-Ramos, L. (2008). The effect of IFRS adoption on trade and foreign direct investments. International Trade and Finance Association Conference Papers, bepress.

Martínez-Ferrero, J. (2014). "Consequences of financial reporting quality on corporate performance: Evidence at the international level." Estudios de Economía 41(1): 49-88.

Mohammed, N. F., et al. (2017). "Accounting conservatism, corporate governance and political connections." Asian Review of Accounting.

Omware, I. M., et al. (2020). "Corporate governance and financial performance of selected commercial banks listed at Nairobi Securities Exchange in Kenya." International Academic Journal of Economics and Finance 3(5): 75-91.

Piot, C., et al. (2011). IFRS consequences on accounting conservatism within Europe: The role of Big 4 auditors, Working paper.

Piot, C., et al. (2010). "IFRS consequences on accounting conservatism within Europe."

Prior, D., et al. (2008). "Are socially responsible managers really ethical? Exploring the relationship between earnings management and corporate social responsibility." Corporate Governance: An International Review 16(3): 160-177.

Richardson, S. (2006). "Over-investment of free cash flow." Review of accounting studies 11(2-3): 159189.

Roychowdhury, S. (2010). "Discussion of:“Acquisition profitability and timely loss recognition” by J. Francis and X. Martin." Journal of Accounting and Economics 49(1-2): 179-183.

Schleicher, T., et al. (2010). "IFRS adoption in Europe and investment-cash flow sensitivity: Outsider versus insider economies." The International Journal of Accounting 45(2): 143-168.

Shan, Y. G. (2015). "Value relevance, earnings management and corporate governance in China." Emerging Markets Review 23: 186-207.

Shima, K. M. and E. A. Gordon (2011). "IFRS and the regulatory environment: The case of US investor allocation choice." Journal of Accounting and Public Policy 30(5): 481-500.

Stein, J. C. (2003). Agency, information and corporate investment. Handbook of the Economics of Finance, Elsevier. 1: 111-165. 
Wang, F., et al. (2015). Financial Reporting Quality, Free Cash Flow, and Investment Efficiency. SHS Web of Conferences, EDP Sciences.

Watts, R. L. (2003). "Conservatism in accounting part I: Explanations and implications." Accounting horizons 17(3): 207-221.

Whittington, G. (2014). Fair value and the IASB/FASB conceptual framework project: an alternative view. Accounting and Regulation, Springer: 229-268. 